\title{
THE LEGAL BACKGROUND OF KINSHIP AS A BASIS OF FAMILY RELATIONSHIPS, WITH SPECIAL REGARD FOR THE REGULATION ON ADOPTION IN CENTRAL EUROPEAN COUNTRIES
}

\section{Edit SÁPI ${ }^{1}$}

The article aims to give an overview of the most significant features of legal regulation on adoption in certain Central European countries. The research was carried out with regard to four countries, namely the Czech Republic, Hungary, Poland, and Slovenia. The article, on the one hand, summarises the legal background, and, on the other hand, presents the relevant constitutional provisions of the given countries. It sheds light on current legal solutions to the relationship between kinship and adoption, then it analyses the requirements of adoption in the four above-mentioned countries. It can be found that the main aim and consequences are the same in all analyzed countries, but there are some national characteristics regarding the types and conditions of adoption. The article shows that one of the most significant principles, the best interest of the child is of utmost importance beside the different national traits of Hungarian, Slovenian, the Czech, and Polish family law.

\begin{tabular}{|c|}
\hline \begin{tabular}{|l} 
adoption \\
kinship \\
family relations in Central Europe \\
best interest of child \\
comparative analysis of adoption \\
family law
\end{tabular} \\
\hline
\end{tabular}

\section{Introduction}

In this article, we provide an overview of the legal regulations of a special kinship relationship, adoption. The article adopts a synthetic analysis and comparison of other countries' legal regulations and solutions.

1 | Assistant Professor, Department of Civil Law, Faculty of Law, University of Miskolc, jogsapi@ uni-miskolc.hu, ORCID: 0000-0001-9152-5950. 
Based on this, we intend to compare the Hungarian, Slovenian, Polish, and Czech legal regulations on the most important issues of adoption. In this article, we place primary emphasis on the overview of the relevant Hungarian rules as a basis and attempt to show the differences and similarities of the other three countries' regulations compared to those of Hungary.

The article is based on the manuscripts ${ }^{2}$ of a future volume about the legal protection of family in Central European Countries; consequently, we use the manuscripts as sources of our work.

The structure of the article follows some main points, such as the relevant legal basis of the countries, the main aim of adoption, and finally the detailed rules of the analyzed countries' legal solutions in line with the given legal institution.

First, it is important to examine the relevant legal environment of the given Central European countries. Approaching the topic from a slightly farther perspective, we can see that the given countries' constitutions also deal with constitution-related issues of family protection as a basis.

The Fundamental Law of Hungary ${ }^{3}$ stipulates that "Hungary shall protect the institution of marriage, the conjugal union of a man and a woman based on voluntary and mutual consent; Hungary shall also protect the institution of the family, which it recognizes as the basis for survival of the nation." 4

The concrete protection of family and parenthood can be found in the Czech Charter of Fundamental Rights and Freedoms, ${ }^{5}$ which declares that "Parenthood and the family are under the protection of the law." 6

Similarly, according to Article 53(2) of the Slovenian Constitution, ${ }^{7}$ legal relations within the family shall be regulated by law and marriage shall be based on the equality of the spouses. ${ }^{8}$

The Constitution of the Republic of Poland ${ }^{9}$ only contains a few provisions on family, such as the privacy of family life and the right to make decisions about personal life. In addition to the privacy of family life, the protection of children is of great importance, especially in two aspects: on the one hand, the children's right to a hearing in proceedings and taking into account their views and, on the other hand, the protection of children deprived of parental care.

The abovementioned points indicate that the given constitutions put emphasis on the legal protection of family, and on the fact that family law and family protection issues shall be governed by law. Generally, it can be stated that the legal regulation of adoption is incorporated into the field of family law in all analyzed countries.

2 | Králíčková, 2021, pp. 77-110., Andrzejewski, 2021, pp. 151-190., Kraljić, 2021, pp. 255-286.

3 | Fundamental Law of Hungary (25 April 2011).

4 | Art. L (1) Fundamental Law of Hungary.

5 | Act No. 2/1993 Coll.

6 | Czech Charter of Fundamental Rights and Freedoms, Art. 32 (2).

7 | Constitution of the Republic of Slovenia. Official Gazette of the Republic of Slovenia Nos. 33/91-I, 42/97, 66/2000, 24/03, 69/04, 68/06, and 47/13.

8 | Slovenian Constitution, Article 53(1).

9| The Constitution of the Republic of Poland of 2 April, 1997. In original language: Konstytucja Rzeczypospolitej Polskiej. 
Examining the Hungarian system from a historical perspective, it is worth mentioning that family law was regulated by a separate act-the former Family Law Act ${ }^{10}$-for a long time, but when the current Civil Code ${ }^{11}$ was accepted in 2013, the family law rules also became an integral part of the 'new' Civil Code in the so-called Family Law Book (the Book V of the Civil Code). Thus, in today's Hungary, family law is part of the Civil Code, but there are several acts and legal sources that can supplement the overall system. Part Four of the Family Law Book of the Civil Code addresses the establishment and termination of kinship and its legal consequences, such as parental responsibility, custody, and child support. This includes family relationships established by adoption, as adoption provides the adopted child with full family status in the family of the adopter. It should be mentioned that the legal sources on adoption are very diverse, since in addition to the Family Law Book of the Civil Code, the Succession Law Book also contains the inheritance effects of adoption. Furthermore, the Act on the Protection of Children (Act XXXI, 1997). Gyvt.) and part of the Guardianship Order (149/1997). (IX. 10.) Order) also contain regulations.

We can observe a similar systematic approach in the Czech legal system as well, where the new Civil Code was adopted in $2012^{12}$ and Family Law was integrated into the Civil Code: Book Two. The basic principles, values, starting points, interpretation, and application rules can be found in Book One: General Part. Given that the Civil Code-like that of Hungary- emphasizes the autonomy of will, it is also fully manifested in Family Law, especially in the area of marital property law. ${ }^{13}$

In the two other Central European countries, the area of family law is regulated by a separate act. In Poland, the Family and Guardianship Code (Act of February 25, 1964) ${ }^{14}$ provides the legal environment for family law affairs, as well as the rules of adoption. The Family and Guardianship Code contains rules on adoption in Section II of Title III, ${ }^{15}$ between Articles 114-127.

We can find a new legal source in Slovenia, since the new Family Code ${ }^{16}$ came into force in April 2019, replacing the more than forty-year-old Marriage and Family Relations Act. ${ }^{17}$ Similar to the Hungarian sample, there are other important additional sources ${ }^{18}$ of family law in the Slovenian system, but the rules of adoption can be found in the Family Code.

\section{The relationship between kinship and adoption}

Regarding the regulation of kinship in the Hungarian system, it can be ascertained that in addition to the biological fact of descent and adoption based on an act of public authority,

10 | Act IV of 1952 on Marriage, Family and Custody .

11 | Act V of 2013 on the Civil Code.

12 | See the Act No. 89/2012 Coll., Civil Code.

13 | Králíčková, 2021, p. 81.

14 | Original Language Title: USTAWA z dnia 25 lutego 1964 r. Kodeks rodzinny i opiekuńczy (Henceforward: Family and Guardianship Code).

15|Article II. Adoption (Przysposobienie) of the Title III. Consanguinity and Affinity (Pokrewieństwo i powinowactwo).

16 | Family Act of 21 March 2017 (Text No. 729). Original title: Družinski zakonik.

17 | Kraljić, 2020, p. 158.

18 | Such as Civil Unions Act and Non-Contentious Civil Procedure Act have. 
there are also actual family relationships, such as the relationship between a stepparent and stepchild, foster parents and foster children, or the child's placement with a family. These relationships are closely aligned with the laws governing kinship. Although the Hungarian Civil Code does not define the concept of 'kinship', it mentions two equivalent institutions, namely blood descent and adoption in connection with the kinship relationship. The Civil Code states that an adoptee receives legal status as the adoptive parent's child. ${ }^{19}$ From the perspective of the child, therefore, no distinction can be observed in the mode of descent, that is, by blood or adoption. It is of utmost importance that a child cannot be discriminated against based on how their parental status was established, that is, whether the child was born out of marriage, cohabitation, or occasional sexual intercourse, or whether they were raised and cared for by biological or adoptive parents. This applies to the family law consequences of the parent-child relationship and to all other legal effects.

In addition, the Czech Civil Code expressly states that family relationships are those between persons based on kinship or adoption. ${ }^{20}$ Thanks to a number of international human rights conventions, the Czech legal order has broadened the protection of a child's natural family. ${ }^{21}$ Similarly, the Czech Civil Code stipulates that kinship is a relationship based on blood ties or adoption ${ }^{22}$ and emphasizes that adoption is a status change. ${ }^{23}$ It is also worth mentioning that the Czech legal literature stresses that the rules on the adoption of minors are in harmony with the international standards established mainly by international covenants and the case law of the European Court of Human Rights. ${ }^{24}$ Polish legal literature interprets adoption as one of the basic family legal relations among marriage and blood kinship, which also constitutes other relationships. ${ }^{25}$

The Family and Guardianship Code of Poland approaches the issues of kinship from the viewpoint of the concept of family. It stresses that the functioning of a family can be understood as a marriage and a two-generation family. It is also worth mentioning that in Polish family law, only the provisions regarding maintenance are applied to all relatives in lineal descent. ${ }^{26}$

In Slovenia, we find a detailed system of adoption. The Slovenian legal system emphasizes that during adoption, the child's ethnic, religious, cultural, and linguistic background should be considered and attempts should be made to ensure the continuity of the child's upbringing in a family environment. ${ }^{27}$

\section{The main aim and consequences of adoption}

Looking at the history of mankind, we can see that adoption has taken many forms, and its purpose and conditions demonstrate a varied picture. If we trace its legal history,

19 | Hungarian Civil Code, Article 4:119 (1) and Article 4:132 (1) .

20 | Czech Civil Code, Article 771.

21 | See in details: Králíčková, 2003, pp. 125-142.

22 | Czech Civil Code, Article 771.

23 | Czech Civil Code, Article 794 ff.

24 | Králíčková, 2021, p. 97.

25 | Kosior, Łukasiewicz, 2018, p. 12.

26 | Andrzejewski, 2021, p. 182.

27 | Kraljić, 2021, p. 279. 
we can see that the purpose of adoption showed the characteristics of a certain age. For example, adoption was a special form of slave liberation in Roman law, and at that time, only adults could be adopted primarily because of succession rights. Feudal society was based on blood kinship; consequently, adoption lost its significance in the Middle Ages. In the New Age, the adoption of minors and adults was already established, and it could also have served to legalize a child born out of wedlock. ${ }^{28}$

As a general feature, we can establish that the main purpose of adoption is the same in all the analyzed Central European countries. In this sense, the aim of adoption is to ensure that minors can be raised in a family in case their biological parents are unable to provide such an environment. This is why all the examined countries regulate adoption in a similar manner.

As its main purpose, the Hungarian ${ }^{29}$ Civil Code highlights that adoption should be considered to establish a family relationship between the adoptive parent, their relatives, and the adopted child in order to allow the child to be raised in a family. ${ }^{30}$ If we would like to provide a definition for adoption from the viewpoint of the main aim of the legal institution, then it can be said that adoption is the admission of a person outside the family as a full member of the family. ${ }^{31}$ In accordance with the Civil Code, the main purpose of adoption is to ensure that minors are raised in a family in case their biological parents are unable to raise them. Adoption can also be briefly defined as the admission of a person outside the family as a full member of the family. Of course, the purpose of the adoption is different in the case of spousal and kinship adoption than in other cases of adoption in which the child is actually adopted by a person outside the family. ${ }^{32}$ Adoption has two main objectives: on the one hand, to establish a family, kinship relationships between the adopter(s) and their relatives, and between the adoptee and its descendants; on the other hand, to ensure the raising of the minor in a family where their physical, moral, and intellectual needs are secured. ${ }^{33}$

The Slovenian Family Code stipulates that adoption is a special form of protection for children that establishes a legal relationship between the adoptive parent and the child equal to the relationship between parents and their children. ${ }^{34}$ The Slovenian legal literature stresses the approach that adoption shall have a so-called ultima ratio nature, since it is a replacement for the original birth family and adoption shall be the last solution. However, in cases the biological family of the child cannot raise the child and protect their best interests, the state is obliged to guarantee and provide this kind of protective environment to the child. ${ }^{35}$

As mentioned above, in Czechia, a new Civil Code was adopted in which new rules affect the consequences of adoption. One rule affects the surname of an adopted child. The Czech legal literature emphasizes that the former rigid rule strictly ordered the change in the child's original surname for the adopters' surname, and this rule was modified. ${ }^{36}$

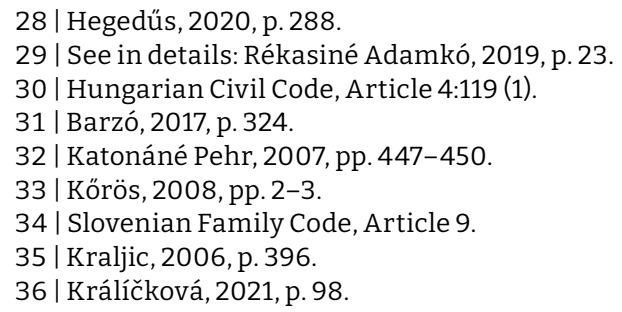


According to the new rule, the court is entitled to allow the adoptee to use both surnames together: their original as well as that of the adopters. ${ }^{37}$

Besides concrete legal regulations, the legal environment of the given countries also emphasizes that adoption is the best option when there is a need for the permanent replacement of the absent parents or their care as part of parental care. This is why adoption can be the best alternative form of care for children who cannot be cared for by their parents. The purpose of adoption is to provide a stable, secure, and caring environment in which the child can grow and develop harmoniously. Consequently, the legal institution is used to replace the family environment and creates a kinship relationship. The main consequence of adoption is similar in the analyzed countries; it changes the legal status of the given child by making the adoptive parents the child's parents who exercise parental control over the child. This approach can also be reflected in the legal regulations mentioned above.

It is also worth mentioning that because of the created kinship, adoption has succession consequences.

According to the Hungarian Civil Code, the adopted child shall be regarded as the parent's child and will not only inherit the adoptive parent's estate but also that of the relatives of the adoptive parents. Adoption shall not affect the adopted person's legal right to inherit from their blood relatives, if adoption was implemented by the adopted person's relative in the ascending line, sibling, or a descendant of such relative in the ascending line. ${ }^{38}$ However, primarily one's own descendants, spouses, and adoptive relatives are entitled to inheritance. The blood relatives of the adopted can inherit only if neither the adoptive nor the relatives can inherit after adoption. ${ }^{39}$ In addition, the Polish Family and Guardianship Code rules that because full adoption modifies the child's legal status, making the adoptive parents his parents, it entitles the parties in the adoption relationship to inherit after each other. ${ }^{40}$

For the same reason-adoption creates kinship-adoption is also a marriage impediment in all examined countries' legal systems, because marriage between an adoptive parent and the adoptee results in the nullity of the marriage.

\section{Types of adoption}

It can be observed that the examined countries regulate various forms of adoption at the domestic level. In addition to national solutions, all of these countries also permit international adoption. ${ }^{41}$ In the following sections, we provide an overview of the domestic features.

The Hungarian Civil Code acknowledges two types of adoption: open adoption and confidential adoption. These forms of adoption were also known and regulated in former

37 | Czech Civil Code, Article 835

38| Hungarian Civil Code, Article 7:72.

39 | Hungarian Civil Code, Article 7:72. See in details: Fábián, 2020, p. 71.

40 | Family and Guardianship Code Article 125.; See also: Kalus, Habdas, 2020, p. 254.

41 | Rékasiné Adamkó, 2019, p. 29. 
civil law legislation. ${ }^{42}$ The Hungarian legislator approaches these two forms from the viewpoint of parental consent.

According to the Civil Code, open adoption means when the biological parent approves the adoption of an adoptive parent known to them. In this case, the parent may withdraw their statement of consent within a period of six weeks following the birth of the child for the benefit of caring for and raising of the child by the parent or another relative of the child. The parents will be informed of the possibility of withdrawal.

On the contrary, confidential adoption occurs when the biological parent agrees with the adoption of their child in a manner that maintains the confidentiality of the person and the identifying information of the adoptive parents, or where the parent's consent is not required in accordance with this act. A statement of consent can be made before the birth of the child. The parent may withdraw their statement of consent within a period of six weeks following the birth of the child for the benefit of caring for and raising of the child by the parent or another relative of the child. The parents will be informed of the possibility of withdrawal. If the child is over six years of age or suffers from any mental disorder, the approval of the guardian is required for the validity of the statement of consent. In the process of confidential adoption, the parent is not notified of the adoption and does not seek remedy against the decision on adoption. In the process of confidential adoption, the natural identification data of the biological parent and the adoptive parent shall not be disclosed to either party.

Three types of adoption can be distinguished in the Polish legal literature: Full adoption, which modifies the child's legal status, making adoptive parents' parents and making them exercise parental custody over the child, and as mentioned above, it affects the rules of succession law and provides maintenance. ${ }^{43}$

There is also complete, or insoluble, or anonymous adoption, which is similar to full adoption and occurs with the so-called permission of a blank mother for adoption. According to the Family and Guardianship Code, complete adoption is adjudicated in the event of the parents' death or their consent to adopt a child without indication of the adopter, is additionally irresolvable. ${ }^{44}$ Thus, we can regard this as similar to Hungarian confidential adoption. Third, the Polish system also recognizes incomplete adoption. The legal literature explains this as when only the relationship between the adopter and the adoptee is created. ${ }^{45}$

The Czech Civil Code also interprets secret adoption when it establishes the option of adoption and the circumstances in which it is to be kept secret from the child's original family. The option of secrecy applies to the children's parents and their consent to adoption. ${ }^{46}$ However, it should be mentioned that when the child reaches the age of eighteen and obtains legal capacity, they are entitled to know the details of the adoption file. ${ }^{47}$ According to the new rules mentioned above, the Czech Civil Code allows the so-called re-adoption, which means the adoption of an already adopted child. In line with the Act, an adopted child may be re-adopted only if:

42 | Barzó, 2017, p. 342.

43 | Andrzejewski, 2021, p. 183.

44 | Family and Guardianship Code, Article 125

45 | Kosior, Łukasiewicz, 2018, p. 60.

46 | Czech Civil Code, Article 837

47| Czech Civil Code, Article 838. 
a) an earlier adoption has been cancelled,

b) (s)he is to be adopted by a subsequent spouse of the adoptive parent after the previous spouse who was a joint adoptive parent died, or

c) the person who was the only adoptive parent or the person who was a joint adoptive parent died. ${ }^{48}$

\section{Conditions of adoption}

The Hungarian legal literature highlights that many legal rules emphasize the permanent nature of adoption, such as the examination of the suitability for adoption, the limited time for the withdrawal of the parents' consent, or the eligibility for adoption. The aim of these guaranteed nature rules is to avoid the injuring of children and to prepare adoptive parents for the tasks necessary in adoption. ${ }^{49}$

\section{| 5.1. Requirements regarding the adopted child}

The Hungarian legal system stipulates some general conditions as a requirement for adoption, such as the adoption of only minors. ${ }^{50}$ We will see that the same is true in Poland and Slovenia, but not in Czech Republic, where not only minors, but adult persons can be adopted as well.

As a general rule, the Hungarian Civil Code stresses that apart from the adoption of the minor child of the spouse, a child can be adopted if their parents are not alive, or if they are unable to raise the child properly. The act also adds that an adopted child may be adopted by the spouse of the adoptive parent or by others after the adoptive parent's death. If an adopted child is adopted after the adoptive parent's death, the previous adoption ceases. Because of these abovementioned factors, the relevant part of the Hungarian Civil Code tries to create a balance between the interests of the child and those of the adoptive or biological parents. ${ }^{51}$

Similar to the Hungarian law, the Polish family law also prescribes that only a minor can be adopted and only for their good, which means that the best interest of the child shall be taken into account during the whole process of adoption..$^{52}$

Similarly, in Slovenia, only children may be adopted. ${ }^{53}$ The Family Code also provides that "a child may be placed for adoption only if the parents have consented to the adoption after the child's birth." 54 This also means that prenatal adoption and prenatal consent for adoption are not possible.

However, as mentioned above, the Czech system is unique in this matter, as it acknowledges the adoption of adults. In Czechia, the adoption of minors is interpreted as a benefit for both real and social orphans, as well as unwanted or abandoned minor children. ${ }^{55}$ Because

48 | Czech Civil Code, Article 843.

49 | Katonáné Pehr, 2020, p. 1.

50 | Hungarian Civil Code, Article 4:119 (2).

51 | Hungarian Civil Code, Article 4:123.

52 | Holewinska-Lapinska, 1994, p. 74.

53 | Slovenian Family Code, Article 212.

54 | Slovenian Family Code, Article 218 (1).

55 | Králíčková, 2021, p. 99. 
of its legal historical roots, Czech Civil Code makes it possible to adopt an adult. The adoption of an adult is regarded as a status change; however, it is not a full change in comparison with the adoption of a minor. The Czech Civil Code prescribes that an adult may be adopted unless it is contrary to good morals. ${ }^{56}$ Czech law distinguishes between two types of adoption in this regard. One is analogous to the full adoption of minors. In this issue, the Civil Code stipulates that an adult may not be adopted if it is contrary to the legitimate interest of his biological parents. ${ }^{57}$ The Act also prescribes that an adult may be adopted if:

a) they are a blood sibling of the child being adopted by the same adoptive parent

b) at the time the application for adoption was filed, the child being adopted was a minor

c) the adoptive parent cared for the child being adopted as his own already when he was a minor or

d) the adoptive parent wishes to adopt the child of his spouse.

The other type of adult adoption is the one that is not analogous to the full adoption of minors, which is also the title of the legal institution in the given article of the act. ${ }^{58}$ This type of adoption is not full adoption when the adoptee remains, especially with regard to the property, connected with his or her family of origin. Additionally, the adoption of an adult does not affect their surname. ${ }^{59}$

\section{| 5.2. Requirements regarding the adoptive parents}

\subsubsection{General requirements of adoption}

The Hungarian Civil Code stipulates the basic rule that any person whose parental supervision has been terminated by court order or who has been excluded from public affairs, and whose child is under foster care may not adopt a child. The act also prescribes that only a person with full legal capacity can adopt a child. The reason for this regulation can also be found in the aim of adoption, that is, the adoptive parents shall exercise parental control over the child after the adoption and need full legal capacity for this. The Civil Code adds that for the adoption, an identical petition shall be submitted by the person wishing to assume the parenting of a child and the child's legal representative, together with the consent of the child's parents and the spouse of the adoptive parent. It is also worth mentioning that a minor of limited legal capacity over the age of fourteen years may be adopted with their consent. A minor of sound mind under the age of fourteen shall be heard and their opinion shall be taken into consideration, where deemed appropriate. ${ }^{60}$ In Hungary, adoption shall be authorized by the guardian authority if the legal requirements are met and if it is deemed to be in the child's best interest. ${ }^{61}$ The Hungarian system also emphasizes that in the adoption process, a degree of continuity should be ensured in line with the child's upbringing with particular regard to their family ties, nationality, religion, mother tongue, and cultural background.

56 | Czech Civil Code, Article 846.

$57 \mid$ Czech Civil Code, Article 847 (2).

58 | Czech Civil Code, Article 848-849.

59 | Czech Civil Code, Article 851 (1).

$60 \mid$ Hungarian Civil Code, Article 4:120.

61 | Hungarian Civil Code, Article 4:120 (1)-(5). 
In contrast, the Czech Civil Code stipulates that adoption is decided by a court on the application of the person who wishes to adopt the child. ${ }^{62}$ However, regarding the general requirement of adoptive parents, the same legal solution is present in Czechia, namely that only an adult person with legal capacity can become an adoptive parent, provided that his personal characteristics and way of life, as well as the reasons and motives that lead him to become an adoptive parent, guarantee that he will be a good parent to the child being adopted.

Similarly, the Slovenian legal system emphasizes that, during adoption, a child's ethnic, religious, cultural, and linguistic background should be considered to ensure the continuity of the child's upbringing in a family environment. ${ }^{63}$

The Polish law stresses that a child can qualify for adoption if their parents fail to exercise parental authority over the child because the parents are dead, unknown, have had their parental authority removed, or have consented to the adoption of their child. ${ }^{64}$

\subsubsection{The issue of age differences}

We can find the same adoption requirements for the given countries. One of the most important requirements of adoption is the age-related issue, that is, whether there is any age difference regulation between the parties, or the age at which one can adopt a child. Determination of the minimum age difference shows the seriousness of adoption, while the maximum age difference is important because it should allow adoptive parents to manage the child in a flexible manner. The significance of the rules on age difference is justified by the fact that adoption can fulfil its purpose if parents undertake the tasks of adoption in a suitable age. ${ }^{65}$

The Hungarian Civil Code establishes concrete regulations regarding the age of the adoptive parent, which must be at least 25 years of age with legal capacity, must be at least 16 years and at most 45 years the child's senior, and who is considered suitable to adopt the child based on their personality and other circumstances. Where an application for the adoption of a child over three years of age is submitted, in the best interest of the child adoption may be authorized if the age difference between the adoptive parent and the child is not more than 50 years. This rule is quite new in the Civil Code because this modification, which allows for a maximum age difference of 50 years between the parties in the case of a child over three years of age, came into effect on March 1, 2021. According to the justification of the modification, this permits a broader possibility for older generations to adopt children. However, the legal literature highlights that the modification will not reach the intended effect, probably because older people would like to adopt younger children. ${ }^{66}$

In the case of adoption by a relative or spouse, the requirement for age differences should not apply. In the case of adoption as a common child, the age and age difference requirement should be satisfied by either of the adoptive parents. If the adoptees are siblings, the age of the older child should be taken into consideration. ${ }^{67}$

62 | Czech Civil Code, Article 796 (1).

63 | Kraljić, 2021, p. 281.

$64 \mid$ Family and Guardianship Code, Article 119a.

65 | Katonáné Pehr, 2020, p. 3.

66 | Katonáné Pehr, 2020, p. 4.

67 | Hungarian Civil Code, Article 4:121(2). 
We can see concrete age relation rules in the Slovenian solution as well, but the minimum age prescribed for adoptive parents is lower than in Hungary, since the Act stipulates that only a person who has reached the majority and is at least eighteen years of age may be an adoptive parent. By exception, a person who is not eighteen years older than the child may be allowed to adopt where all the circumstances of the case have been examined, and it is established that such an adoption would be in the best interests of the child. ${ }^{68}$

We can also find the rules on age differences in Czech family law, but these are not as concrete as those in the domestic Hungarian model. The Czech Civil Code prescribes that there must be a reasonable age difference between the adoptive parent and the child being adopted, typically not less than 16 years. The act stipulates as an exception, that the age difference between the adoptive parent and the child being adopted may be less than 16 years only where a guardian representing the child in the proceedings consents to the adoption and the adoption is in accordance with the child's interests. ${ }^{69}$

Polish law also emphasizes that the adoptive parent shall be suitably older than the adopted child and shall be in full legal capacity. ${ }^{70}$ Such suitability is ascertained at the adoption center, which issues a certificate of the completion of relevant training and an opinion on whether the candidate is qualified to adopt a child.

\subsubsection{Rules regarding the family status of the adoptive parents}

Another interesting issue in adoption concerns whether a single person or persons living in de facto cohabitation or in a same-sex partnership are entitled to adopt or not and, if they can, on what conditions.

In Hungary, a child may only be adopted by married couples, except where the child is adopted by a relative or by the parent's spouse. Registered partners and de facto cohabitants cannot adopt children. Consequently, the joint adoption of a child by same-sex partners is not allowed. A single person can adopt a child only with the license of the given minister in a justified case.

Slovenian family law prescribes that children maybe adopted jointlyby spouses or extramarital partners. Under the law, these two partnerships can only be established by partners of different sexes. In Slovenia, same-sex partners cannot adopt a child together. In addition to joint adoption, the law also allows for so-called single adoption. Stepparent adoption occurs if a spouse or extramarital partner adopts the child of their spouse or extramarital partner. This is also carried out exceptionally for a child if it is impossible to obtain adoptive parents who are spouses or extramarital partners, and if this is in the child's best interests. In this case, such a child will also be adopted by one person. In the case of single adoption, a partner from a civil union or de facto civil union can adopt their partner's child. ${ }^{71}$

Cohabitants and same-sex partners are not allowed to adopt a child jointly in Poland because joint adoption is only open to spouses. In Polish legal practice, it is also impossible to adopt one's partner's child because this would lead to the termination of the legal relationship between the child and the parent. Married couples may adopt a child, but it is also possible for a single person to adopt. $^{72}$

68 | Slovenian Family Code, Article 215.

69 | Czech Civil Code, Article 803.

70 | Kosior, Łukasiewicz, 2018, p. 59.

71 | Kraljić, 2021, p. 282.

72 | Andrzejewski, 2021, p. 182. 
In the Czech Republic, only married couples are jointly entitled to adopt a child. Besides adoption by a married couple, the law enables adoption by one of the spouses and exceptionally by another person. It is also worth mentioning that the Czech system allows so-called re-adoption, the adoption of an already adopted child..$^{73}$

\section{The process of adoption and pre-adoption care}

The adoption procedure in Poland can be divided into three stages: the first stage occurs at the adoption center. At this level, a selection of adopters is made for the adopted child and they are provided with appropriate training. In the second stage, the court issues a decision about adoption. The third stage takes place before the head of the civil registry office, where the child's birth certificate is issued. ${ }^{74}$

In this process, pre-adoption care is of utmost importance because it is the most significant benchmark of eligibility for adoption, which can predetermine the relationship between the adoptive parents and the adopted child..$^{75}$

According to Hungarian law, ${ }^{76}$ the person wishing to assume the parenting of a child shall provide care for the child in their own home for a period of at least one month. Adoption may be authorized without the period of care in the case if

a) the adoptive parent and the biological parent are married

b) the adoptive parent has been caring for the child in their own home for at least one year with the biological parent's consent, or

c) the child being cared for is adopted by their child protection foster parent, who has been providing childcare and upbringing for a period of at least one year.

The act prescribes that adoption may be authorized if this period of caring for the child proves to be successful. After the mandatory care period has expired, the person who wishes to adopt the child clarifies their intentions.

In Czechia, pre-adoption care is also obligatory, but lasts a longer period of time than in Hungary, having been extended from three months to not less than six months. ${ }^{77}$ The new legal rule states that after the parents' consent to adoption and placing the child on the pre-adoption care of the prospective adopters, the exercise of parental responsibility of the child's parents is suspended by the operation of law, ${ }^{78}$ and the court must appoint a guardian for the adoptee. The maintenance obligation of the child's parents or other persons is also suspended, as prospective adoptive parents are required to keep the child with them at their own expenses. ${ }^{79}$

73 | Králíčková, 2021, 98.

74 | Kosior, Łukasiewicz, 2018, p. 60.

75 | Barzó, 2017, p. 338.

76 | Hungarian Civil Code, Article 4:128.

77 | Czech Civil Code, Article 829.

$78 \mid$ Czech Civil Code, Article 825.

79 | Czech Civil Code, Article 829. 


\section{Conclusions}

In this article, we outlined the most important factors and features of adoption in four Central European countries. Generally, the most significant characteristics of the observed area are similar in the four countries, which can be traced back to the common continental legal premises and principles and a similar historical background.

The main purpose, aim, and consequences of adoption are the same in the examined countries, but some differences exist regarding the detailed rules of the types, forms of adoption, the necessary consents, and the prescribed age-related rules.

In light of historical developments, adoption is quite an ancient legal institution the origin of which can be traced back to Roman Law. If we would like to examine the future of adoption, we need to consider some data regarding the number of adoptions.

In the Czech system, regulations on adoption have undergone significant changes because of the new concept of the new Civil Code, such as re-adoption or the adoption of adult persons. Some modifications can be regarded as old-new approaches, such as the adoption of adults, which try to return to the historical roots..$^{80}$

In recent years in Poland, adoption has been regarded as less attractive because of the availability of artificial forms of procreation, which can allow parents to experience parenthood almost from conception. Another important reason is the ease with which the adopted learn about their own roots, which prompts them to establish relationships with the biological family. ${ }^{81}$

The Slovenian manuscript shows that in 2017 in Slovenia, 593 applications were filed for adoption. Two years later, there were 47 adoptions. Thus, many couples in Slovenia wish to adopt a child, but there are not enough children eligible for adoption. The majority of children are adopted by the child's parent spouse or partner. Since the Slovenian legal regime allows single adoption, single persons may adopt four children. As a general number, it can be observed that the waiting period of potential adopters can be more than ten years. This situation may be eased by the possibility of international adoption, and some couples are willing to adopt a child from abroad. ${ }^{82}$

A similarity can be observed regarding the Hungarian situation since couples regarded as eligible for adoption must wait approximately two to five years for a child because the adoptive parents have preferences and wishes regarding the children. Hungarian practice shows that if a couple is more open to a child, they can adopt it easier and earlier. ${ }^{83}$ The Hungarian legal environment and practice put great emphasis on the issues of parents' eligibility, which covers the adoption preparation course.

Despite the abovementioned and detailed domestic features, characteristics that are sometimes different in Hungary, Slovenia, Czechia, and Poland, the most important message and aim of adoption remains the same, which is consideration for the best interests of the child. 


\section{Bibliography}

Andrzejewski, M. (2021) 'Legal Protection of the Family: Essential Polish provisions regarding international legal standards and social change' in Barzó, T., Lenkovics, B. (eds.) Family Protection From a Legal Pesrpective - Analysis on Certain Central European Countries, Budapest-Miskolc: Ferenc Mádl Institute of Comparative Law, Central European Academic Publishing, pp.151-190.

I Barzó T. (2017) A magyar család jogi rendje. Budapest: Patrocinium Kiadó.

Fábián, F. (2020) 'A törvényes öröklés általános rendje, az osztályrabocsátás, a házastárs öröklése leszármazó mellett, az ági öröklés. Az állam öröklése. Az örökbefogadással kapcsolatos öröklési jogi szabályok' in Sándor, I. (ed.) Polgári jog III. Budapest: Patrocinium Kiadó.

Hegedűs, A. (2020) ‘Az örökbefogadás célja, feltételei, joghatásai, hatálytalanná válása és felbontása' in Sándor, I. (ed.) Polgári jog III. Budapest: Patrocinium Kiadó.

Holewinska-Lapinska, E (1994) 'The Legal Procedures for Adopting Children in Poland by Locan Citizens and by Foreign Nationals' in Jaffe, E. D. (ed.) Intercountry Adoptions: Laws and Perspectives of "sending" Countries, Gefen Publishing House Ltd.

Kalus, S., Habdas, M. (2020) Family and Succession Law in Poland, Kluwer Law International B.V.

Katonáné Pehr, E. (2007) 'Az örökbefogadás' in Kőrös, A. (ed.) A családjog kézikönyve Vol I. Budapest: HVG-Orac Kiadó, 447-450.

Katonáné Pehr, E (2020) ‘A gyermek érdeke az örökbefogadás új jogi környezetében. A gyermekközpontú örökbefogadás követelménye’, Családi jog, 2020/3.

Kőrös, A. (2008) 'Fontolva haladás - az új Ptk. Családjogi Könyve: Az örökbefogadás I.', Családi Jog, 2008/1, pp. 1-8.

Kosior, W. J., Łukasiewicz, J. M. (2018) Family Law in Poland, Rzeszów: Legal Publishing House.

Králíčková, Z. (2003) 'Adoption in the Czech Republic: Reform in the Light of the Child Welfare Laws' in Bainham, A. (ed.) The International Survey of Family Law. Bristol: Jordan Publ. Limit, pp. 125-142.

Králíčková, Z. (2013) 'On the family and family law in the Czech Republic' in Barzó, T., Lenkovics, B. (eds.) Family Protection From a Legal Pesrpective - Analysis on Certain Central European Countries, Budapest-Miskolc: Ferenc Mádl Institute of Comparative Law, Central European Academic Publishing, pp. 77-110.

Kraljic, S. (2006) Legal regulation of adoption in Slovenia - Do we need changes? The International Survey of Family Law.

Kraljić S. (2020) 'New family code and the dejudicialization of divorce in Slovenia', Balkan Social Science Review, Vol.15, pp.158-176.

Kraljić, S. (2021) ‘Family protection in Slovenia’ in Barzó, T., Lenkovics, B. (eds.) Family Protection From a Legal Pesrpective - Analysis on Certain Central European Countries, Budapest-Miskolc: Ferenc Mádl Institute of Comparative Law, Central European Academic Publishing, pp. 255-286.

Rékasiné Adamkó, A. (2019) ‘Feltétel nélkül szeretni és szeretvelenni - azörökbefogadás Magyarországon az európai szabályozás tükrében', Családi jog, 2019/4. pp. 23-30. 